A N N A L E S

UNIVERSITATIS MARIAE CURIE-SKŁODOWSKA

LUBLIN - POLONIA

VOL. LXII, 2

SECTIO G

2015

KRZYSZTOF WALCZAK

\title{
Praktyczne problemy z interpretacją zasady niedyskryminacji w wynagradzaniu
}

Practical Problems with Interpretation of the Principle of Non-Discrimination in Remuneration

\section{WSTĘP}

Problematyka równości w wynagradzaniu ${ }^{1}$ została omówiona w literaturze, dlatego w niniejszym opracowaniu pragnę zasygnalizować niektóre praktyczne problemy związane z wdrażaniem tej zasady w autonomicznych źródłach prawa pracy obowiązujących u pracodawców przedsiębiorcó $w^{2}$ w oparciu o dokonane przeze mnie w latach 2009-2013 badania 450 układów zbiorowych pracy (dalej: ZUZP) i regulaminów wynagradzania ${ }^{3} . \mathrm{Z}$ analizy tej wyłania się obraz rzeczywistości, która niestety w wielu miejscach odbiega od założeń teoretycznych i dlatego uważam, że dobrze by było, aby stała się przedmiotem analizy i refleksji ${ }^{4}$.

1 Moją koncepcję tego pojęcia przedstawiłem m.in. w opracowaniu: Aksjologiczne podstawy wynagradzania zatrudnionych $w$ gospodarce postindustrialnej - wybrane zagadnienia, [w:] Aksjologiczne podstawy prawa pracy i ubezpieczeń społecznych, pod red. M. Skąpskiego, K. Ślebzaka, Poznań 2014, s.183 i n.

2 Szerzej na ten temat piszę w opracowaniu: Autonomiczne źródła prawa dotyczacego wynagradzania, „Monitor Prawa Pracy” 2014, nr 1, s. 8 i n.

3 Autorski katalog zasad wynagradzania zawarłem w opracowaniu: Zasady wynagradzania pracowników wynikające z prawa pracy $i$ ich porównanie z praktyka firm oraz teoria zarządzania personelem, [w:] Aktualne problemy zarzadzania - teoria i praktyka. Monografia naukowa z okazji 40-lecia Wydziału Zarzadzania Uniwersytetu Warszawskiego, Warszawa 2012, s. 187 i n.

4 Ogólne informacje na ten temat przedstawiłem w opracowaniu: Problematyka wynagradzania pracowników w układach zbiorowych pracy. Teoria i praktyka początku drugiej dekady XXI wieku w świetle poglądów Wactawa Szuberta, [w:] Układy zbiorowe pracy. W stulecie urodzin Profesora Wacława Szuberta, pod red. Z. Górala, Warszawa 2013, s. 304 i n. 
Na wstępie należy wskazać, że jest to chyba najtrudniejsza do interpretacji z wydzielonych przeze mnie zasad wynagradzania, gdyż opiera się, jak żadna inna, na założeniach aksjologicznych, co oznacza, że zmiana uwarunkowań i podejścia osób oceniających do kwestii równości sprawia, że jej interpretacja ma charakter bardzo dynamiczny w ujęciu historycznym. $Z$ tego powodu należy określić jako punkt odniesienia cechy relewantne stanowiące podstawę do uzasadnionego różnicowania wynagradzania, które nie będzie oceniane jako dyskryminujące. Bardzo dobrze oddaje te dylematy wyrok SN z dnia 2 lipca 2012 roku, I PK 48/125. Przepisy zawarte w rozdziale IIa k.p., podobnie jak prawo wspólnotowe, nie zawierają normy, z której miałoby wynikać, że wszyscy pracownicy danego pracodawcy mają być równo traktowani. Przepisy te określają natomiast kryteria (przyczyny), które nie mogą uzasadniać różnicowania sytuacji zatrudnionych. Oznacza to, że za dyskryminowanego można uznać tylko takiego pracownika, który wykonując pracę jednakową lub jednakowej wartości, ma wynagrodzenie ukształtowane na niższym poziomie niż inny pracownik, jeżeli ta różnica wynika z jednej lub kilku przyczyn, o których mowa w art. $18^{3 a} \S 1$ k.p.

\section{JEDNAKOWA PRACA I PRACA JEDNAKOWEJ WARTOŚCI}

Na potrzeby realizacji zasady niedyskryminacji w wynagradzaniu istotne jest rozgraniczenie dwóch pojęć: ,jednakowa praca” i „praca jednakowej wartości”. Na pierwszy rzut oka wydaje się proste wskazanie jednakowych prac, za których wykonywanie należy się jednakowe wynagrodzenie. Jak wskazuje się w orzecznictwie w sytuacji, gdy w strukturze organizacyjnej pracodawcy występują stanowiska, na których świadczona jest jednakowa praca (rozumiana jako praca taka sama pod względem rodzaju i kwalifikacji wymaganych do jej wykonywania oraz ilości i jakości), nie zachodzi konieczność porównywania - przy pomocy kryteriów określonych w art. $18^{3 c} \S 3$ k.p. - prac różniących się rodzajowo ${ }^{6}$, bowiem ,jednakowa praca" w rozumieniu art. $18^{3 \mathrm{c}}$ k.p. odnosi się nie do nazwy stanowiska, lecz do wykonywanych przez pracownika obowiązków ${ }^{7}$. W praktyce odnalezienie jednakowej pracy w tym rozumieniu może być jednak problematyczne, ponieważ nawet na prostych stanowiskach zakresy zadań, a więc i pracy, mogą być różne, dlatego też - jak słusznie wskazuje się w orzecznictwie - nie chodzi tutaj o ,zegarmistrzowskie” porównywanie, ale o dostrzegalne różnice. Przyjęcie odmiennego założenia, tj. uznanie, że niewielkie, drobne różnice $\mathrm{w}$ wynagrodzeniu mogą być uznane za dyskryminację, jeśli tylko praca ma cechy, o których mowa w art. $18^{3 \mathrm{c}} \S 1$ k.p., prowadziłoby do sytuacji, w której de facto sądy kształtowałyby siatkę płac u pracodawców, co jest niedopusz-

5 Legalis.

6 Wyrok SN z dnia 18 września 2008 roku, II PK 27/08, OSNAPiUS 2010, nr 3-4, poz. 41, s. 130 .

Wyrok SN z dnia 12 stycznia 2010 roku, I PK 138/09, Legalis. 
czalne ${ }^{8}$. Mimo pewnych trudności praktycznych z egzemplifikacją pojawiających się różnic wynagradzanie za jednakową pracę nie budzi tylu wątpliwości, co za pracę jednakowej wartości, bowiem w tym drugim przypadku wymagane jest stworzenie pewnych mierników, które z konieczności muszą się opierać na pewnych założeniach aksjologicznych ich autorów ${ }^{9}$, co będzie przedmiotem dalszych rozważań. Wszystko to sprawia, że nie udało się stworzyć jednego uniwersalnego modelu oceny pracy, chociaż wydaje się, że najbardziej akceptowalny jest model wartościowania stanowisk pracy. Moim zdaniem tylko w taki „naukowy” sposób można porównać prace zupełnie innego rodzaju ${ }^{10}$. Pogląd ten opieram na osobistych doświadczeniach prowadzenia przez ponad pięć lat wartościowania stanowisk pracy i dlatego mogę stwierdzić, że prawidłowo przeprowadzony proces z udziałem przedstawicieli wszystkich komórek pracodawcy daje bardzo dobre wyniki, nie tylko porządkując stanowiska i tworząc obiektywny i dopasowany do wymogów organizacji taryfikator ${ }^{11}$, ale tam gdzie wykorzystuje się metody uniwersalne, daje to podstawę do budowania rynkowych zasad wynagradzania, co zwłaszcza obecnie w czasie walki konkurencyjnej jest uznawane za jedno z istotnych narzędzi konkurencyjnej polityki personalnej ${ }^{12}$.

\section{PRZYCZYNY UZASADNIAJĄCE RÓŻNICOWANIE WYNAGRADZANIA}

Tak jak wskazałem wyżej, ponieważ nie ma jednej prostej definicji wskazującej, co jest, a co nie jest dyskryminacją w wynagradzaniu, dlatego w celu realizacji tej zasady należy wskazać cechy, które leżały u podstaw różnicowania

8 Zob. wyrok SN z dnia 12 stycznia 2010 roku, I PK 138/09, Legalis. Podobny pogląd zaprezentował SN w wyroku z dnia 7 kwietnia 2011 roku, I PK 232/10, OSNAPiUS 2012, nr 11-12, poz. 133, s. 442.

9 Przejawem takiego podejścia są chociażby wypowiedzi MOP, które wskazują, że konieczne jest przełamywanie stereotypów, iż prace mogą być klasyfikowane jako typowo „męskie” lub „kobiece". Dlatego w procesie nadzoru zwraca się uwagę, aby kryteria wartościowania nie deprecjonowały zajęć oraz kwalifikacji i umiejętności wymaganych do realizowania pracy z reguły wykonywanej przez kobiety i/lub dowartościowywały wymaganie niezbędne do realizowania prac z reguły wykonywanych przez mężczyzn. Szerzej zob. A.M. Świątkowski, Międzynarodowe prawo pracy, t. 1: Międzynarodowe publiczne prawo pracy - standardy międzynarodowe, Vol. 2, Warszawa 2008, s. 188.

10 Stanowisko takie potwierdza także wypowiedź Komisji Ekspertów ds. Konwencji i Zaleceń MOP, w której wskazuje się, że państwa, które ratyfikowały Konwencję nr 100, nie spełniają jej wymogów, jeżeli nie uznają, że zakaz dyskryminacji w wynagradzaniu nie dotyczy tylko przypadków, w których mężczyzna i kobieta wykonują taką samą pracę, ale również pracę o jednakowej wartości, nawet jeżeli ta praca ma zupełnie różny charakter (Raport Komisji Ekspertów na 88 sesję MKP, Genewa 2000; Rapport III [partie 1A] de la Commission d'experts pour l'application des conventions et recommandations, s. 285).

11 Przykładowy proces wartościowania opisałem w opracowaniu: Wartościowanie stanowisk pracy ustawowym obowiazkiem pracodawcy?, „Monitor Prawa Pracy” 2004, nr 9, s. 241 i n.

12 Szerzej piszę na ten temat w opracowaniu: Regionalizacja wynagrodzeń a zasada niedyskryminacji pracowników, „Gdańskie Studia Prawnicze” 2013, t. XXX, s. 225 i n. 
i ocenić, czy mają one przymiot relewantności. W jaki sposób należy dokonać tego różnicowania, wskazuje TK, który co prawda kieruje swoje uwagi w stosunku do ustawodawcy, ale wydaje się, że można je bezpośrednio zastosować w stosunku do podmiotów decydujących o kwestiach wynagradzania. W wyroku z dnia 23 października 2001 roku $^{13}$ czytamy, że jeżeli prawodawca różnicuje podmioty prawa, które charakteryzują się wspólną cechą istotną, to wprowadza on odstępstwo od zasady równości. Odstępstwo takie jest dopuszczalne, jeżeli zostały spełnione trzy warunki. Po pierwsze, wprowadzone przez prawodawcę różnicowania muszą być racjonalnie uzasadnione. Muszą one mieć związek z celem i treścią przepisów, w których jest zawarta kontrolowana norma. Po drugie, waga interesu, któremu ma służyć różnicowanie podmiotów podobnych, musi pozostawać w odpowiedniej proporcji do wagi interesów, które zostaną naruszone w wyniku różnego traktowania podmiotów podobnych. Po trzecie, różnicowanie podmiotów podobnych musi znajdować podstawę w wartościach, zasadach lub normach konstytucyjnych.

Ze względu na to, że w zakresie wynagradzania cech tych jest bardzo dużo, poniżej skupię się tylko na kilku, które w świetle orzecznictwa, doktryny i zwłaszcza praktyki analizowanych podmiotów występują często, a z drugiej strony mogą być kontrowersyjne.

\section{Wynagradzanie w okresie wypowiedzenia oraz po ustaniu stosunku pracy}

Pierwszą cechą, która stanowi często podstawę różnicowania w wynagradzaniu jest status pracownika, a więc czy jest on w okresie wypowiedzenia albo czy wręcz w momencie przyznania konkretnego świadczenia jest nadal zatrudniony, a składnik ten dotyczy okresu, w którym pracownik wykonywał pracę. Wydaje się bezdyskusyjne od strony formalnej, że pracownik znajdujący się w okresie wypowiedzenia powinien być tak samo traktowany, jak pozostali zatrudnieni. Pogląd ten był od dawna prezentowany w judykaturze. Przykładowo zgodnie z wyrokiem SN z dnia 13 listopada 1990 roku, I PR 352/90 ${ }^{14}$, pracownikowi w okresie wypowiedzenia przysługują te same uprawnienia - łącznie z uprawnieniem do wynagrodzenia w określonej wysokości - co innym pracownikom zakładu pracy. Jeśli więc wszystkim pracownikom zakładu zostały przyznane podwyżki wynagrodzeń, a pominięto tylko powoda $\mathrm{z}$ tej racji, iż znajduje się w okresie wypowiedzenia, należy to traktować jako nieuzasadnioną szykanę i naruszenie prawa. Argumentów dla takiego podejścia jest, moim zdaniem, bardzo dużo. Skoro w okresie wypowiedzenia należy oczekiwać od pracownika takiego samego wykonywania pracy, jak od pozostałych, czego przejawem jest możliwość rozwiązania umowy

13 K 22/01, OTK, nr 7, poz. 215.

14 OSP 1992, nr 3, poz. 55 z glosą T. Bińczyckiej-Majewskiej. 
o pracę bez wypowiedzenia $\mathrm{z}$ winy pracownika $\mathrm{w}$ okresie biegnącego wypowiedzenia, to nie widzę podstaw, aby od strony wynagradzania okres ten traktować inaczej. Praktyka taka jest natomiast powszechna, o czym świadczą analizowane przeze mnie autonomiczne źródła prawa pracy, uzależniające wypłatę świadczeń, w tym zwłaszcza wynikowych, od niebycia na okresie wypowiedzenia ${ }^{15}$. Jednak, co gorsza, na takie nierówne traktowanie zezwala również SN, który np. w wyroku z dnia 24 stycznia 2002 roku $^{16}$ wskazuje, że pracodawca nie ma prawnego obowiązku jednakowego ukształtowania warunków wynagradzania pracownika, któremu wypowiedział umowę o pracę i pracowników dalej zatrudnianych. Pogląd taki wydaje mi się a priori nieuzasadniony i ewidentnie dyskryminujący, a także naruszający zasadę ekwiwalentności zmodyfikowanej, chyba że pracodawca byłby $\mathrm{w}$ stanie udowodnić obiektywnymi powodami, że w konkretnym przypadku ma to związek z pracą, która ma być wykonywana w przyszłości, a więc że jest to pewnego rodzaju zaliczka na konto przyszłego wynagrodzenia. Z praktyki doradczej wiem, że takie przypadki występują jednak niezwykle rzadko.

Analogicznie należy moim zdaniem traktować sytuacje, gdy konkretne składniki wynagradzania dotyczą okresu, w którym pracownik był zatrudniony, jednakże w momencie ich przyznawania lub naliczania stosunek pracy ustał. Pogląd ten potwierdza uchwała SN z dnia 21 listopada 1991 roku $^{17}$, w której czytamy, że nieważne jest postanowienie regulaminu wynagrodzenia za pracę, wprowadzonego w spółce z ograniczoną odpowiedzialnością, wyłączające prawo pracownika do nagrody (premii) z zysku za okres rozliczeniowy w razie rozwiązania umowy o pracę po upływie tego okresu. Zgodnie z innym wyrokiem SN z dnia 23 października 1996 roku $^{18}$ pominięcie byłego pracownika przy przyznawaniu świadczenia, będącego składnikiem wynagrodzenia za pracę w okresie, w którym był on zatrudniony, narusza zasady wynagradzania za pracę wykonaną (art. 80 k.p.), wynagradzania według ilości i jakości pracy (art. 78 k.p.) i równego traktowania pracowników (art. $11^{2}$ k.p.). A contrario zatem argumentacja dla takiego różnego traktowania musiałaby być bardzo mocna i wskazywać, podobnie jak w przypadku omówionej wyżej sytuacji pracownika znajdującego się w okresie wypowiedzenia, że konkretny składnik wynagrodzenia jest wypłacony z góry na poczet

15 Przykładowo w jednym $\mathrm{z}$ regulaminów obowiązującym u pracodawcy $\mathrm{z}$ branży finansowej czytamy, że pracownicy objęci systemem premiowym uzyskują prawo do wypłaty z jego tytułu, jeżeli spełnią warunki, z których jednym jest pozostawanie w stosunku pracy w dniu wypłaty. Jednocześnie pracownicy nie mogą: znajdować się w okresie wypowiedzenia umowy o pracę, mieć podpisanego porozumienia stron odnośnie rozwiązania umowy o pracę, złożyć bądź otrzymać wypowiedzenie umowy o pracę (wyjątek stanowią wypowiedzenia z przyczyn niedotyczących pracownika).

16 I PKN 16/01, OSNAPiUS 2004, nr 3, poz. 44, s. 113.

17 I PZP 59/91, PUG 1992, nr 5, s. 121.

18 I PRN 94/96, OSNAPiUS 1997, nr 8, poz. 131. 
przyszłej pracy, np. związanej z konkretnym projektem, lub też - co jednak nie występuje w poprzednim przypadku - jest świadczeniem okolicznościowym, do którego uprawnienie związane jest $\mathrm{z}$ byciem w zatrudnieniu. Uzasadniony $\mathrm{z}$ tego powodu wydaje się pogląd wyrażony w wyroku SN z dnia 12 września 2006 roku $^{19}$, zgodnie z którym prawo do premii z okazji Bożego Narodzenia nabywali tylko pracownicy zatrudnieni w dacie jej wypłaty. Nie była to premia za pracę w oznaczonym okresie (roku), lecz dla osób zatrudnionych w określonym dniu.

\section{Wymiar czasu pracy oraz rodzaj umowy}

W okresie gospodarki industrialnej modelowy pracownik był zatrudniony na podstawie umowy o pracę na czas nieokreślony w pełnym wymiarze czasu i on też był adresatem wszystkich uprawnień, podczas gdy inni pracownicy, jako kategorie faktycznie nietypowe, wielokrotnie byli ich pozbawieni ${ }^{20}$. Aby temu zapobiec, ustawa z dnia 19 lipca 1990 roku o zmianie ustawy o zasadach tworzenia zakładowych systemów wynagradzania oraz zmianie niektórych innych ustaw ${ }^{21}$ wprowadziła do słowniczka pojęć zwrot, że pod pojęciem ,pracownika” rozumie się także osoby zatrudnione w niepełnym wymiarze czasu pracy ${ }^{22}$. Zakaz różnego traktowania tych osób w stosunku do ,typowych” pracowników został jednoznacznie uregulowany w k.p. od dnia 1 stycznia 2004 roku, kiedy wprowadzono przepisy zakazujące różnicowania wynagrodzenia ze względu na wymiar czasu pracy oraz rodzaj umowy. Czym się przejawia ten zakaz? Jeżeli chodzi o osoby zatrudnione w niepełnym wymiarze czasu, to co do zasady ich wynagrodzenie za pracę winno być proporcjonalne do wynagrodzenia pracowników zatrudnionych „,na pełnym etacie”. Nie istnieją jednak przepisy, które zakazałyby firmie zwiększyć wymiar czasu pracy pracownika bez podniesienia wynagrodzenia. Takie stanowisko wyraził SN w wyroku z dnia 17 września 2008 roku $^{23}$. W tym kontekście poważne wątpliwości budzi, moim zdaniem, art. $151 \S 5$ k.p. wskazujący, że stro-

19 I PK 89/06, MoPr 2007, nr 2, s. 88.

20 Praktyka taka była jednak kwestionowana, czego przykładem może być wyrok SN z dnia 21 czerwca 1977 roku, I PRN 43/77 (OSNCP 1978, nr 1, poz. 17), zgodnie z którym postanowienie zakładowego regulaminu rozdziału nagród indywidualnych z zakładowego funduszu nagród, wyłączające prawo do nagrody pracownika zatrudnionego na pół etatu, jeżeli w innym zakładzie pracy pracuje on na pełnym etacie, jest sprzeczne z ustawą z dnia 23 czerwca 1973 roku o zasadach tworzenia i podziału zakładowego funduszu nagród oraz zakładowych funduszów socjalnego i mieszkaniowego i powzięte z naruszeniem $\S 6$ rozporządzenia Rady Ministrów z dnia 1 października 1973 roku w sprawie zakładowego funduszu nagród, jest nieważne i nie może pozbawić pracownika prawa do tej nagrody.

${ }^{21}$ Dz.U., nr 55, poz. 319.

22 Na wagę tego doprecyzowania zwracał uwagę Z. Salwa, Nowelizacja przepisów o tworzeniu zakładowych systemów wynagradzania, „Praca i Zabezpieczenie Społeczne” 1990, nr 10, s. 31.

23 Wyrok SN z dnia 17 września 2008 roku, I PK 128/08, MoPr 2009, nr 5, s. 226. 
ny ustalają w umowie o pracę dopuszczalną liczbę godzin pracy ponad określony $\mathrm{w}$ umowie wymiar czasu pracy pracownika zatrudnionego $\mathrm{w}$ niepełnym wymiarze czasu pracy, których przekroczenie uprawnia pracownika, oprócz normalnego wynagrodzenia, do dodatku do wynagrodzenia, o którym mowa w art. $151^{1} \S 1$ k.p. Może to prowadzić do dyskryminacji à rebours, gdy za pracę taką samą lub takiej samej wartości oraz - co ważniejsze - tej samej ilości i jakości pracownik pełnoetatowy może otrzymać mniejsze wynagrodzenie. Dylemat ten nie jest prosty do rozwiązania, ponieważ powstaje pytanie, czy sytuacja tych dwóch grup zatrudnionych jest taka sama, a więc czy jest to czynnik relewantny. Rozumiejąc argumenty pokazujące, że przepis ten ma na celu zapobieganie patologiom związanym z zatrudnianiem na niepełny etat pracowników, którzy stale wykonują pracę w pełnym wymiarze, nie wydaje mi się, aby to był najlepszy sposób jej niwelowania. Lepsze mogłoby być wystąpienie do sądu o stwierdzenie, że praca w rzeczywistości jest wykonywana w pełnym wymiarze czasu ${ }^{24}$, dlatego zgadzam się z poglądem wyrażonym przez $\mathrm{SN}$, że jest to element negocjacyjny i jeżeli strony nie uregulują tego w umowie, to wówczas zasady wynagradzania są takie same, jak w przypadku pełnoetatowców ${ }^{25}$.

Bardziej ewidentny jest zakaz różnicowania wynagradzania pracowników ze względu na rodzaj umowy, tymczasem w aktualnie obowiązujących aktach prawa zakładowego znajdujemy w tym zakresie przykłady regulacji ewidentnie dyskryminacyjnych ${ }^{26}$.

Natomiast niezwykle ciekawym fenomenem, który wymaga moim zdaniem głębszej analizy ze względu na stosunkowo częste stosowanie w aktualnie wydawanych źródłach autonomicznego prawa pracy, a czego nie spotykaliśmy w okresach poprzednich, są postanowienia mające na celu skłonienie pracowników w wieku przedemerytalnym za pomocą „zachęt finansowych” do rozwiązania stosunku pracy w momencie osiągnięcia wieku emerytalnego ${ }^{27}$. Jeżeli chodzi o spo-

24 Pogląd taki prezentuje zresztą SN w uchwale z dnia 4 kwietnia 2014 roku, I PK 249/13, MoPr 2014, nr 5, s. 226.

25 Takie zresztą podejście prezentuje ETS. Zgodnie z orzeczeniem C 399/92 Helmig and Schmidt art. 119 (obecnie 141) TWE i dyrektywa 75/117 nie zabraniają układom zbiorowym pracy ograniczenia wynagrodzenia za pracę w godzinach nadliczbowych tylko do tych przypadków, w których przekroczony zostaje czas pracy ustalony dla pracowników zatrudnionych w pełnym wymiarze czasu pracy.

26 Przykładowo w jednym z regulaminów wynagradzania uzależniono prawo do nagrody jubileuszowej od zatrudnienia na czas nieokreślony.

27 Regulacje te, mające na celu ułatwienie zatrudnienia pracowników wchodzących na rynek pracy, a równocześnie zwiększające elastyczność zatrudnienia, są zresztą akceptowane przez UE, czego przejawem jest wyrok ETS z dnia 22 listopada 2005 roku, C-144/04 Werner Mangold v. Rüdiger Helm, zgodnie z którym klauzula 8 pkt 3 Porozumienia ramowego w sprawie pracy na czas określony, zawartego w dniu 18 marca 1999 roku, wprowadzonego w życie przez dyrektywę Rady 1999/70/WE z 28 czerwca 1999 roku dotyczącą Porozumienia ramowego w sprawie pracy 
sób wprowadzenia tej instytucji, to można wyodrębnić jej trzy formy. Pierwszą jest zmiana rodzaju umowy o pracę z bezterminowej na terminową na podstawie porozumienia stron umowy. Drugą - rozwiązanie umowy o pracę na czas nieokreślony na mocy porozumienia stron $\mathrm{z}$ datą osiągnięcia wieku emerytalnego. Trzecią zaś - rozwiązanie umowy o pracę za wypowiedzeniem dokonanym przez pracownika. W przypadku wyrażenia przez pracownika zgody na ustanie stosunku pracy w momencie osiągnięcia wieku emerytalnego, pracodawca przyznaje mu następujące uprawnienia: albo wzrost wynagrodzenia zasadniczego o $5-10 \%{ }^{28}$, albo przyznanie stawki płacy zasadniczej $\mathrm{w}$ ramach kategorii zaszeregowania bezpośrednio wyższej niż wynikająca z umowy o pracę ${ }^{29}$. Czy takie uregulowanie można uznać za wystarczające uzasadnienie różnicowania wynagrodzenia, a więc czy jest to cecha relewantna? Wydaje mi się, że tak, gdyż w tym przypadku, jeżeli oczywiście decyzja pracownika jest dobrowolna, występuje tutaj korzyść zarówno dla pracownika, jak i dla pracodawcy, ale również dla społeczeństwa. Co więcej, trudno porównywać osobę, która dobrowolnie rezygnuje z dalszego zatrudnienia, a więc i źródła zarobkowania, z pracownikiem, który nadal wykonuje pracę, a więc otrzymuje wynagrodzenie ${ }^{30}$. Dlatego jestem zwolennikiem uznania takiej praktyki za usprawiedliwioną, co nie zmienia faktu, że kłóci się ona z podstawową zasadą wynagradzania, jaką jest ekwiwalentność zmodyfikowana.

na czas określony, zawartego przez Europejską Unię Konfederacji Przemysłowych i Pracodawców (UNICE), Europejskie Centrum Przedsiębiorstw Publicznych (CEEP) oraz Europejską Konfederację Związków Zawodowych (ETUC), należy interpretować w ten sposób, że klauzula ta nie stoi na przeszkodzie uregulowaniu krajowemu, takiemu jak stanowiące przedmiot postępowania przed sądem krajowym, które ze względu na konieczność promowania zatrudnienia i niezależnie od wykonywania tego porozumienia dokonało obniżenia granicy wieku, po przekroczeniu której możliwe jest zawieranie umów o pracę na czas określony bez ograniczeń.

28 Zgodnie $\mathrm{z}$ regulaminem obowiązującym w jednym z banków pracownik zatrudniony u pracodawcy przez co najmniej 10 lat, który cztery lata przed emeryturą zdecyduje się zmienić umowę na czasową, kończącą się z dniem nabycia uprawnień emerytalnych, otrzyma wzrost wynagrodzeń o 5\%.

29 Oto przykładowe zapisy dotyczące tej tematyki. ZUZP z przedsiębiorstwa z branży przemysłowej pracownikom, w okresie poprzedzającym bezpośrednio dwa lata przed uzyskaniem prawa do emerytury, którzy posiadają co najmniej 10-letni staż pracy w spółce i zawrą z pracodawcą w formie pisemnej umowę o rozwiązaniu stosunku pracy na zasadzie porozumienia stron w dniu następnym po uzyskaniu prawa do emerytury, pracodawca przyzna stawkę płacy zasadniczej w ramach kategorii zaszeregowania bezpośrednio wyższą o jedną kategorię, niż wynika to z zawartej umowy o pracę. Nieco inaczej kwestię tę uregulowano natomiast w ZUZP w jednej z elektrowni, zgodnie z którym wprowadza się możliwość przyznania kategorii „S” (o jedną wyżej niż przysługująca na danym stanowisku) pracownikom w wieku przedemerytalnym na rok przed planowanym odejściem na emeryturę.

30 Szerzej piszę na ten temat w opracowaniu: Postanowienia autonomicznych źródet prawa pracy obowiązujących u pracodawców - przedsiębiorców zwiększające wymiar emerytury, [w:] Materiaty pokonferencyjne IV Seminarium Szubertowskie. Współczesne problemy prawa emerytalnego, pod red. M. Włodarczyka (w druku). 


\section{Staż pracy}

Kryterium stażu pracy jako uzasadnienie różnicowania nie tylko wysokości wynagrodzenia zasadniczego, ale również przyznawania innych świadczeń, było w gospodarce industrialnej powszechnie akceptowane, co znajdowało swoje bezpośrednie odzwierciedlenie w przepisach zarówno rangi ustawowej, jak i układowej. Najbardziej widocznym przejawem stosowania tej zasady są dodatki stażowe i nagrody jubileuszowe, które również w początkowym okresie obowiązywania przepisów o niedyskryminacji nie budziły szczególnej wątpliwości i były jednym z tych elementów różnicujących, które uznawano w każdym przypadku za dopuszczalne. Jak wskazuje TK w uzasadnieniu wyroku z dnia 7 maja 2001 roku $^{31}$, o wysokości wynagrodzenia decyduje w polskich warunkach także okres dotychczasowego zatrudnienia lub zatrudnienia $\mathrm{w}$ jednym zakładzie pracy. Wiązało się to $\mathrm{z}$ przeświadczeniem, że dłuższy staż wiąże się z większymi kwalifikacjami oraz związaniem z pracodawcą ${ }^{32}$. Reprezentatywna w tym względzie jest uchwała SN z dnia 27 marca 2007 roku $^{33}$, w uzasadnieniu której czytamy, że niekwestionowanym przy tym kryterium (miernikiem) nakładu pracy, któremu powinno odpowiadać wynagrodzenie za pracę (jego wysokość), jest staż pracy czy długość przyczyniania się pracownika (pracowników) do osiągnięcia pozytywnych efektów (zwłaszcza gospodarczych), pozwalająca na różnicowanie wysokości wynagrodzenia pracowniczego, zwłaszcza w skali kwartału czy roku.

Czy takie bezkrytyczne podejście da się obecnie obronić? Wydaje się, że nie, a za taką tezą przemawia kilka argumentów. Po pierwsze, sama aksjologia tego rodzaju świadczeń. Dodatek stażowy został wprowadzony w drugiej połowie lat 70. w wyniku postulatów załóg, które widziały w nim ekwiwalent za utratę sił i zmniejszoną wydajność pracy w starszym wieku. Jak wskazywano, z upływem czasu predyspozycje psychiczne i umysłowe zatrudnionych, a w ślad za tym i wydajność, osiągają maksymalny poziom, po czym następuje spadek. Z tego powodu brak jest podstaw do awansowania tych pracowników. Konsekwencją takiej polityki jest powstawanie dysproporcji płacowych między pracownikami o dłuższym i krótszym stażu pracy. Jako drugi argument podawano potrzebę uznawa-

31 K 19/00, OTK 2001, nr 4, poz. 82.

32 Przykładowo w przypadku nagrody jubileuszowej uzasadniano to tym, iż motywuje ona i jednocześnie nagradza pracownika za długoletnie pozostawanie w stosunku pracy z danym pracodawcą. Jest to pewne odwzajemnienie, bowiem pracodawca zwykle czerpie korzyści płynące z długotrwałej więzi łączącej pracownika z danym zakładem. Staż taki wyposaża pracownika w wiedzę i umiejętności, które w poważnym stopniu uzupełniają posiadane przez niego wykształcenie. Długoletnia praca zwiększa również emocjonalną i osobistą więź z zakładem, co zmniejsza ryzyko powstania konfliktów i sporów. Zob. M. Piankowski, Ochrona pracowniczych świadczeń majątkowych, Bydgoszcz - Gdańsk 2002, s. 63.

33 II PZP 3/07, OSNAPiUS 2007, nr 17-18, poz. 243, s. 706. 
nia i opłacania doświadczenia jako formy wyższych kwalifikacji ${ }^{34}$. A jako trzeci wskazywano, że jest to zachęta do kontynuowania zatrudnienia dla doświadczonych i sprawdzonych pracowników - stanowiących swego rodzaju strategiczny zasób pracodawcy - a w konsekwencji przeciwdziałanie odchodzeniu z pracy pracowników najbardziej cennych dla pracodawcy.

Te założenia można obecnie $\mathrm{w}$ gospodarce postindustrialnej stosunkowo łatwo obalić. Ustawodawca zalicza w sposób arbitralny do okresów pracy, od których uzależnione są uprawnienia pracownicze, nie tylko okresy wykonywania pracy w rozumieniu k.p., ale również inne wybrane okresy niemające wiele wspólnego z nabywaniem kwalifikacji i uprawnień, co jest szczególnie widoczne w sektorze budżetowym ${ }^{35}$. Jako przykłady można podać okresy pracy w gospodarstwie rolnym na zasadach określonych w ustawie z dnia 20 lipca 1990 roku o wliczaniu okresów pracy w indywidualnym gospodarstwie rolnym do pracowniczego stażu pracy $^{36}$, odbytej czynnej służby wojskowej na warunkach wynikających z art. 120 ustawy z dnia 21 listopada 1967 roku o powszechnym obowiązku obrony Rzeczypospolitej Polskiej ${ }^{37}$ czy pobierania zasiłku dla bezrobotnych zgodnie $\mathrm{z}$ art. 79 ust. 1 ustawy z dnia 20 kwietnia 2004 roku o promocji zatrudnienia i instytucjach rynku pracy ${ }^{38}$, które w większości przypadków nie mają wiele wspólnego z nabywaniem kwalifikacji, a więc i ze sposobem wykonywania pracy. Z drugiej strony nie przewiduje się zaliczania okresów zatrudnienia na podstawie umów cywilnoprawnych czy samozatrudnienia, które w wielu przypadkach umożliwiają nabycie lepszych kwalifikacji niż w przypadku zatrudnienia pracowniczego, nie mówiąc już o okresach nieświadczenia pracy. Należy też wskazać na poglądy teorii zarządzania personelem, której przedstawiciele podkreślają, że wynagradzanie pracowników za staż pracy powoduje, iż otrzymują oni różną płacę za taką samą pracę, co nie zawsze jest odbierane jako sprawiedliwy sposób wynagradzania ${ }^{39}$. Nie każde bowiem wydłużenie stażu pracy przyczynia się do wzrostu doświadczenia. Może ono być mniej lub bardziej wszechstronne, zdobywane szybciej lub wolniej, zależne od indywidualnych ocen pracownika ${ }^{40}$.

34 Z. Jacukowicz, Zmiany wewnętrznej struktury wynagrodzeń, Warszawa 1996, s. 36.

35 Szerzej na ten temat piszę w opracowaniu: Prawo urzędnicze. Komentarz, pod red. K.W. Barana, Warszawa 2014 - w komentarzach do regulacji wynagrodzeniowych członków służby cywilnej, pracowników samorządowych, urzędów państwowych oraz sądów i prokuratury.

36 Dz.U., nr 54, poz. 310. Szerzej zob. T. Libera, Komentarz ustawy z 20.07.1990 r. o wliczaniu okresów pracy $w$ indywidualnym gospodarstwie rolnym do pracowniczego stażu pracy, [w:] Prawo pracy. Akty wykonawcze. Komentarz, pod red. W. Muszalskiego, K. Walczaka, Warszawa 2002, s. 83 i n.

37 Dz.U. z 2012 roku, $\mathrm{nr} 461$ ze zm.

38 Dz.U. z 2013 roku, nr 674 ze zm.

39 K. Lanz, Zatrudnianie i zarzadzanie personelem, Warszawa 1994, s. 66.

40 L. Kozioł, A. Piechnik-Kurdziel, J. Kopec, Zarzadzanie zasobami ludzkimi w firmie. Teoria i praktyka, Warszawa 2000, s. 272. 
W sektorze prywatnym najczęściej występuje staż zakładowy, ale pojawia się również staż branżowy, który jednak ulega coraz większej erozji ze względu na niemal zupełny zanik powszechnie stosowanych w poprzednim okresie ponadzakładowych układów zbiorowych pracy ${ }^{41}$. Natomiast fenomenem ostatnich lat, który wynika z moich badań, jest odpowiadające na zupełne niedopasowanie do realiów gospodarczych pojęcia pracodawcy zarządczego, a nie właścicielskiego ${ }^{42}$, stosowanie stażu korporacyjnego ${ }^{43}$. Pojawia się wreszcie pojęcie stażu nieprzerwanego $0^{44}$.

Jak widać, pojęcie stażu pracy może być bardzo różnie rozumiane, dlatego można zadać pytanie, o który staż chodzi jako uzasadnienie różnicowania wysokości wynagrodzenia i przyznawania innych świadczeń. Pytanie to zaczynają również zadawać sądy, i to nie tylko polskie, ale też międzynarodowe. Jak wskazuje przykładowo TSUE w wyroku z dnia 3 października 2006 roku (C 17/05) w sprawie B.F. Cadman przeciwko Health \& Safety Executive, pracodawca nie musi co prawda specjalnie udowadniać, iż odwołanie się do kryterium stażu pracy jest odpowiednie dla zróżnicowania wynagrodzeń, gdyż chodzi o wynagrodzenie zdobytego doświadczenia, które pozwala pracownikowi lepiej wywiązywać się ze swoich obowiązków, chyba że pracownik przedstawi okoliczności mogące wzbudzić poważne wątpliwości pod tym względem. Podobny pogląd zaprezentował SN w tezie 2 wyroku z dnia 22 lutego 2007 roku $^{45}$, zgodnie z którym przy powołaniu się pracodawcy na różne kwalifikacje zawodowe i staż pracy oznacza to konieczność wykazania, że miały one znaczenie przy wykonywaniu zadań powierzonych pracownikom ${ }^{46}$.

${ }^{41}$ Szerzej piszę na ten temat w opracowaniu: Dopuszczalność zwolnienia się z postanowień ponadzakładowego układu zbiorowego pracy przez pracodawców indywidualnych, [w:] Aktualne zagadnienia prawa pracy..., s. 253 i n.

42 Szerzej piszę na ten temat w opracowaniu: Pojęcie pracodawcy $w$ polskim prawie pracy $i$ wynikajace z niego problemy praktyczne, [w:] Aktualne zagadnienia prawa pracy..., s. 41 i n.

43 Oto przykład postanowienia z regulaminu wynagradzania z firmy z branży IT: „1. Pracownik może otrzymać premię w wysokości i na zasadach określonych w odrębnych regulacjach wprowadzonych i ogłoszonych przez Pracodawcę lub przedstawiciela Grupy [...]. 2. Pracodawca uznaniowo może udzielić pracownikom także inne świadczenia zgodnie z zasadami obowiązującymi u Pracodawcy lub w Grupie [...]. 3. Szczegółowe informacje o możliwości uzyskania świadczeń, o których mowa w ust. 2, pracownicy mogą uzyskać w informatycznej sieci wewnętrznej Pracodawcy".

44 Oto przykład postanowienia z regulaminu z firmy z branży FMCG: „1. Pracownikom Spółki, zatrudnionym w [...] Polska Sp. z o.o. co najmniej 5 lat na podstawie obowiązującego stosunku pracy, przysługuje miesięczny dodatek stażowy. 2. Do stażu pracy, o którym mowa w ust. 1, bierze się pod uwagę nieprzerwany okres pracy u pracodawcy".

45 I PK 242/06, OSNAPiUS 2008, nr 7-8, poz. 98, s. 294; wyrok SN z dnia 28 kwietnia 2010 roku, II PK 324/09, Legalis.

46 Szerzej na ten temat piszę w opracowaniu: Staż pracy jako podstawa różnicowania wynagrodzenia pracowników. Teoria i praktyka, „Monitor Prawa Pracy” 2014, nr 3, s. 117 i n. 
Problemy ze świadczeniami stażowymi, w tym zwłaszcza z nagrodami jubileuszowymi, stara się rozwiązać praktyka. Co prawda, zgodnie z moimi badaniami liczba podmiotów, w których przyznawane są nagrody jubileuszowe jest nadal znaczna, tzn. 114, to jednak widoczny jest coraz bardziej trend do ich zastępowania innymi świadczeniami odroczonymi, takimi jak pracownicze programy emerytalne.

$\mathrm{Na}$ zakończenie rozważań o kwestiach stażowych należy wreszcie wskazać, że w niektórych autonomicznych źródłach prawa pracy jest on wiązany ze świadczeniami mającymi zupełnie inny charakter. Przykładowo w ZUZP z branży spożywczej czytamy, że wynagrodzenie chorobowe wynosi $80 \%$ - w przypadku pracowników, których staż ogólny (liczony według zasad ustawowych) wynosi mniej niż 15 lat, 90\% - gdy staż ten wynosi co najmniej 15 lat, zaś 100\% przy stażu co najmniej 25-letnim. Czy takie postanowienie obroni się w świetle aktualnie obowiązującego przepisu art. $18^{3 \mathrm{~b}} \S 2$ pkt 4 k.p., który stanowi, że zasady równego traktowania $\mathrm{w}$ zatrudnieniu nie naruszają działania, proporcjonalnie do osiągnięcia zgodnego z prawem celu różnicowania sytuacji pracownika, polegającego na stosowaniu kryterium stażu pracy przy ustalaniu zasad wynagradzania, co uzasadnia odmienne traktowanie pracowników ze względu na wiek - mam co do tego poważne wątpliwości.

\section{Szczególne grupy pracowników, w tym high potentials}

Kwestią, która wzbudzała i wzbudza duże kontrowersje w zakresie wynagradzania jest występowanie w prawie autonomicznym szczególnych grup pracowników, którym przyznaje ono specjalne uprawnienia. W gospodarce planowej zjawisko to było nazywane „kategorie specjalne” i jego stosowanie znajdowało poparcie w doktrynie. Jak wskazywał W. Szubert, potrzeba indywidualizowania wynagrodzenia dla pracowników o szczególnych kwalifikacjach uwzględnianajest $\mathrm{w}$ formie upoważnienia kierownictwa zakładu pracy do posługiwania się w pewnych przypadkach tzw. ryczałtami wykraczającymi w określonych granicach poza stawki taryfowe ${ }^{47}$. Zdaniem M. Święcickiego wynagrodzenie wybitnych specjalistów może być ustalane na warunkach szczegółowych, które zamieszcza się w umowach o pracę. Podobnie dzieje się w przypadku, gdy wprawdzie nie chodzi o szczególnie rzadką specjalność, ale o stanowisko nieprzewidziane w wykazach obejmujących rodzaje prac i stanowiska typowe. W tych przypadkach znajduje zastosowanie zasada, że postanowienia umów o pracę korzystniejsze dla pracownika od postanowień układu zbiorowego pracy są ważne ${ }^{48}$.

47 W. Szubert, Uklady zbiorowe pracy, Warszawa 1960, s. 170.

48 Tak M. Święcicki (Prawo pracy, Warszawa 1963, s. 413), cytując wyrok SN z dnia 15 listopada 1956 roku, PiZS 1957, nr 3, s. 58, 
W badanych przeze mnie aktach autonomicznego prawa pracy, aby mieć możliwość swobody wynagradzania takich osób, pojawia się eufemistyczny zwrot „wynagrodzenie ad personam" ${ }^{\prime 4}$. Bardzo często w stosunku do tych osób stosuje się coraz popularniejszą $\mathrm{w}$ nowoczesnym podejściu do kształtowania wynagrodzeń formę pakietową. Istotą tej formy jest to, iż podstawą do ustalania wynagrodzenia jest ogólny zbiór środków, spośród których wyróżnia się składniki obejmujące wynagrodzenie stałe, zmienne, krótkoterminowe i długoterminowe oraz świadczenia dodatkowe. Pracodawca zgodnie ze swoimi celami i strategią kształtuje pulę środków na wynagrodzenia, z której dobiera odpowiednie składniki pod kątem możliwości kompleksowego motywowania poszczególnych pracowników ${ }^{50}$.

Wszystkie te regulacje miały jednak charakter wyjątkowy, tymczasem w obecnej zglobalizowanej gospodarce postindustrialnej coraz częściej pojawia się kategoria tzw. pracowników wiedzy, których definiuje się jako pracowników reprezentujących wysoki stopień wiedzy specjalistycznej, wykształcenia lub doświadczenia, a do najważniejszych celów ich pracy należy tworzenie, rozpowszechnianie lub praktyczne wykorzystanie wiedzy ${ }^{51}$. Ze względu na posiadaną wiedzę to właśnie oni decydują o sposobie wynagradzania bardziej niż podmiot, w którym wykonują pracę, ponieważ w ich przypadku czas i miejsce pracy nie mają znaczenia, gdyż mogą ją wykonywać wszędzie ${ }^{52}$. Wynagrodzenia takich pracowników są negocjowane indywidualnie przy zachowaniu pełnej poufności, co oznacza, że autonomiczne źródła prawa u takich pracodawców w zasadzie ograniczają się tylko do stwierdzenia, że wynagrodzenie ma charakter indywidualny i poufny ${ }^{53}$.

49 Przykładowo w regulaminie jednego z banków czytamy, że w szczególnie uzasadnionych przypadkach pracodawca może wprowadzić wynagrodzenie ad personam lub odstąpić od wymogów taryfikatora. Natomiast zgodnie z ZUZP obowiązującym w jednej z elektrociepłowni Dyrektor Generalny, w ramach posiadanych środków na wynagrodzenia, może zaszeregować pracownika wyżej od ustalonej maksymalnej grupy zaszeregowania na zasadach tzw. ad personam, informując o podjętych decyzjach zakładowe organizacje związkowe raz na kwartał w ujęciu ilościowym i stanowiskowym. Natomiast w innym banku możliwość ta została bardziej sformalizowana, gdyż odpowiednie postanowienie regulaminu wynagradzania brzmi: „W indywidualnie uzasadnionych wypadkach Prezes Zarządu Banku może podnieść górną granicę stawki wynagrodzenia o kwotę nieprzekraczającą 25\% max stawki zaszeregowania określonej w załączniku 2 oraz/lub wyrazić zgodę na powierzenie pracownikowi stanowiska mimo niespełnienia warunków podanych w załączniku nr 1 do regulaminu".

50 S. Borkowska, Strategie wynagrodzeń, Kraków 2001, s. 96.

51 T.H. Davenport, Zarządzanie pracownikami wiedzy, Kraków 2007, s. 22.

52 K. Prechuta, Zarządzanie wiedza w przedsiębiorstwie, Warszawa 2005, s. 210.

53 Przykładowo w ZUZP jednej ze spółek medialnych czytamy, że Zarząd może przyznać $\mathrm{w}$ indywidualnych przypadkach wynagrodzenie zasadnicze wyższe niż określone dla danego stanowiska. Może to być spowodowane charakterem wykonywanej pracy, zakresem wykonywanych zadań lub ze względu na posiadanie niezbędnych i rzadkich (deficytowych) kwalifikacji koniecznych do funkcjonowania przedsiębiorstwa. W praktyce pracownicy ci otrzymują szereg dodatków, których pozbawieni są ,zwykli pracownicy”. 
Drugą grupą „,szczególnie uprzywilejowanych” są tzw. high potentials. Pojawienie się tej kategorii pracowników jest związane z powstałą w ostatnich latach koncepcją zarządzania kompetencjami oraz wynagradzaniem za kompetencje, a nie za wykonywaną pracę ${ }^{54}$. Podstawą wynagradzania tych pracowników są nie tylko kwalifikacje i doświadczenie, ale również umiejętności, zdolności, cechy psychofizyczne i predyspozycje do pełnienia ról i zajmowania określonych stanowisk. Pracownicy wynagradzani są za posiadany potencjał, zaś wzrost wynagrodzenia zależy od stopnia poszerzania przez nich zakresu wiedzy i umiejętności. Stosowanie takiego podejścia uniemożliwia w praktyce realizację wymogu wyceny pracy wynikającej z k.p.

\section{JAWNOŚĆ WYNAGRADZANIA}

Oprócz wskazanych wyżej problemów z określeniem relewantności cech dających podstawę do różnicowania wynagradzania, drugim najważniejszym moim zdaniem - problemem związanym ze stosowaniem zasady niedyskryminacji jest tajność wynagradzania, bowiem aby przeciwdziałać jej naruszeniom, należy mieć wiedzę na temat zasad przyznawania poszczególnych składników wynagradzania oraz ich wysokości ${ }^{55}$.

Rozwiązanie tego problemu nie jest jednak sprawą prostą, ponieważ należy pamiętać, że informacji na temat faktycznej wysokości indywidualnych wynagrodzeń poszczególnych pracowników pracodawca nie ma prawa upubliczniać. Szczególnie wyraźnie pogląd ten ujawnił się w tezie 2 uchwały z dnia 16 lipca 1993 roku $^{56}$, zgodnie z którą ujawnienie przez pracodawcę bez zgody pracownika wysokości jego wynagrodzenia za pracę może stanowić naruszenie dobra osobistego w rozumieniu art. 23 i 24 ustawy z dnia 23 kwietnia 1964 roku - Kodeks cywilny ${ }^{57}$. Wysokość indywidualnego wynagrodzenia pracownika jako dana osobowa również jest przedmiotem ochrony ustawy z dnia 29 sierpnia 1997 roku o ochronie danych osobowych ${ }^{58}$.

54 Jak wynika z regulaminu jednej z badanych firm usługowych, program high potentials umożliwia rozwój i przynależność do grupy najzdolniejszych pracowników, którym zapewnia się podniesienie kwalifikacji zawodowych, wzięcie udziału w sesjach rozwojowych, warsztatach, panelach dyskusyjnych, pracy z mentorem, wymianę doświadczeń między uczestnikami projektu. Po zakończeniu programu jego uczestniczy mają zagwarantowane objęcie wyższych stanowisk i automatyczny awans.

55 Ponadto reguły te powinny być znane pracownikom ze względu na konieczność stosowania zasady formalizmu, o której piszę w opracowaniu: Zasada formalizmu wynagradzania w ujęciu historycznym, [w:] Materiały pokonferencyjne V Seminarium Szubertowskiego. 40 lat Kodeksu pracy, pod red. Z. Górala (w druku).

56 I PZP 28/93, OSNCP 1994, nr 1, poz. 2.

57 Dz.U., nr 16, poz. 93 (t.j. Dz.U. z 2014 roku, poz. 121 ze zm.).

58 Dz.U. z 2002 roku, nr 101, poz. 926 ze zm. 
Pojawia się pytanie, co się stanie, jeżeli mimo tego zakazu przedstawiciel pracodawcy przekaże takie informacje pracownikowi ,walczącemu” o swoje prawa. Odpowiedzi w świetle prawa pracy udziela art. $18^{3 e} \S 2$ k.p., zgodnie z którym pracownika, który udzielił $\mathrm{w}$ jakiejkolwiek formie wsparcia pracownikowi korzystającemu z uprawnień przysługujących z tytułu naruszenia zasady równego traktowania w zatrudnieniu, nie można traktować w niekorzystny sposób, a także nie może to powodować jakichkolwiek negatywnych konsekwencji, zwłaszcza nie może stanowić przyczyny uzasadniającej wypowiedzenie przez pracodawcę stosunku pracy lub jego rozwiązanie bez wypowiedzenia.

W oparciu o ten przepis SN w wyroku z dnia 26 maja 2011 roku $^{59}$ wskazał, iż przekazanie przez pracownika innym pracownikom danych objętych klauzulą poufności wynagrodzeń w celu przeciwdziałania nierównemu traktowaniu i przejawom dyskryminacji płacowej nie może stanowić podstawy rozwiązania z nim umowy o pracę ani stosowania innych sankcji prawa pracy ${ }^{60}$. Pogląd ten, aczkolwiek aksjologicznie zasadny, może być jednak podważony przez pryzmat ustawy z dnia 29 sierpnia 1997 roku o ochronie danych osobowych ${ }^{61}$, dlatego należałoby podchodzić do interpretacji tej instytucji prawnej w zakresie wynagradzania w sposób bardzo ostrożny.

Nie ulega natomiast wątpliwości, że w celu realizacji zasady niedyskryminacji wydaje się niedopuszczalne akceptowanie poglądu, że pracodawca ma prawo zakazać ujawniania informacji o swoich wynagrodzeniach przez samych zainteresowanych pracowników ${ }^{62}$ albo odmówić udzielenia stosownych informacji za zgodą zainteresowanego związkom zawodowym. Praktyka taka jest zresztą kwestionowana bezpośrednio przez SN, który w uzasadnieniu cytowanej wyżej uchwały z dnia 16 lipca 1993 roku wskazuje, że gdy interesy konkretnego pracownika są zagrożone $\mathrm{w}$ zakresie kształtowania jego wynagrodzenia za pracę i zwróci się on do związku zawodowego o zbadanie tej kwestii lub wyrazi na to zgodę, wówczas niezbędne do prowadzenia działalności związkowej jest uzyska-

59 II PK 304/10, MoPr 2011, nr 10, s. 528.

60 Podobny pogląd wyrażono w wyroku SN z dnia 15 lipca 2011 roku, I PK 12/11, MoPr 2011, nr 12, s. 618.

${ }_{61}$ Dz.U. z 2015 roku, poz. 2135 ze zm.

62 Pogląd ten popiera T. Liszcz (Prawo pracy, Warszawa 2011, s. 297). Podobnie zdaniem MPiPS zabranianie podwładnym rozmawiania o zarobkach może w szczególnych przypadkach sprzyjać dyskryminacji płacowej i utrwalać zaszłości i patologie (pismo DPR I-0712-18/MF/08). Teoria zarządzania zasobami ludzkimi również pokazuje liczne argumenty za umożliwieniem pracownikom rozmawiania o swoich zarobkach. I tak zwolennicy motywacyjnej teorii sprawiedliwości wskazują, że ludzie oczekują efektu proporcjonalnego do włożonego wysiłku, zaś równe traktowanie oznacza traktowanie sprawiedliwe w porównaniu z inną osobą (zob. M. Armstrong, Zarządzanie zasobami ludzkimi, Kraków 2007, s. 217). Każdy pracownik porównuje własną sytuację z sytuacją innego pracownika, a jeżeli nie może tego zrobić, bo uniemożliwia mu to czynnik zewnętrzny, prowadzi go to do demotywacji. 
nie informacji o wysokości wynagrodzenia tego pracownika i na podstawie art. 28 ustawy z dnia 23 maja 1991 roku o związkach zawodowych pracodawca ma obowiązek takiej informacji związkowi zawodowemu udzielićc3.

Jako dodatkowy prawnoporównawczy argument za nieakceptowaniem uznania dopuszczenia zasady tajemnicy wynagradzania w stosunku do samych zainteresowanych można wskazać ustawodawstwo innych krajów. Przykładowo w USA jako naruszenie prawa uważa się działanie pracodawcy, który zakazywałby pracownikom rozmawiać na temat swoich wynagrodzeń z kolegami z pracy, co ma umożliwić im walkę o poprawę warunków pracy ${ }^{64}$.

Jaka jest praktyka w Polsce? Otóż z prowadzonych przeze mnie badań wynika, że w 85 firmach znajdują się zapisy mówiące o tym, że wynagrodzenie pracownika ma poufny charakter i stanowi tajemnicę służbową ${ }^{65}$. W jednym z regulaminów zapisano wręcz, że nawet kategoria zaszeregowania danego stanowiska jest informacją poufną ${ }^{66}$. A contrario w innym z regulaminów znalazłem postanowienie, że dostęp do informacji o wysokości wynagrodzeń jest jawny, co stanowi ewidentne naruszenie przepisów ustawy o ochronie danych osobowych, a poza tym budzi sprzeciw samych pracowników, jednakże ze względu na obawę o miejsce pracy nie sprzeciwiają się oni oficjalne takiej praktyce.

63 Jako ciekawostkę można wskazać, że postanowienie to zostało wpisane do dwóch z badanych ZUZP, w których czytamy, że wysokość wynagrodzenia jest co prawda tajemnicą służbową, ale upoważnieni przez związek zawodowy przedstawiciele mają prawo uzyskać informacje o indywidualnych wynagrodzeniach. W innym ZUZP czytamy zaś, że informacja o wysokości wynagrodzenia indywidualnie oznaczonego pracownika jest jego dobrem osobistym i w tym zakresie może być udostępniona osobom trzecim tylko za zgodą pracownika. Związkom zawodowym udostępnia się indywidualne dane o wynagrodzeniach w sposób zapewniający uniemożliwienie imiennej identyfikacji pracownika.

${ }_{64}$ R.J. Nobile Essential Facts: Employment Edition 2010-2011, Danvers 2010, s. 1173.

65 Przykładowo w regulaminie jednej z firm z branży FMCG czytamy: „Wysokość wynagrodzenia pracownika stanowi informację poufną. Oznacza to, że pracownik zobowiązany jest nie ujawniać w okresie trwania stosunku pracy oraz w okresie 3 lat po jego rozwiązaniu wysokości swojego wynagrodzenia za pracę innym osobom lub instytucjom, w tym także pracownikom, [...] z wyjątkiem sytuacji, gdy prawo lub obowiązek ujawniania wysokości wynagrodzenia określonym instytucjom przewidują powszechnie obowiązujące przepisy”. Jeszcze bardziej kuriozalne postanowienie znajdujemy w regulaminie pracy jednego ze sklepów sieciowych, zgodnie z którym pracownik ma prawo wglądu tylko do stawek zaszeregowania właściwych dla swojego stanowiska pracy. Pracownik jest obowiązany do zachowania w tajemnicy wysokości swojego wynagrodzenia oraz wysokości obowiązujących na jego stanowisku stawek zaszeregowania.

66 Symptomatyczna w tym względzie jest wypowiedź pracownika jednej z badanych firm, który stwierdził, że ponieważ oficjalną polityką wewnętrzną firmy jest nierozmawianie o wysokości swoich zarobków, stąd trudno jest nawet ustosunkować się do kwestii, czy są one mniejsze/większe czy porównywalne do stawek rynkowych. Można jednak przypuszczać, iż dla części osób są one, w połączeniu z innymi profitami, na tyle atrakcyjne, aby w tej pracy pozostać (niska rotacja), a jednocześnie nie na tyle wysokie, aby w ostentacyjny sposób zwracało to uwagę osób postronnych (obserwacja własna). 


\section{PODSUMOWANIE}

Zaprezentowane wyżej wybrane problemy ze sposobem interpretacji zasady niedyskryminacji w wynagradzaniu pokazują, że określenie prawidłowości działania pracodawcy w tym zakresie jest niezwykle trudne i opiera się głównie na aksjologii oceniającego. Aby zobiektywizować tę subiektywną ocenę, wydaje się niezwykle istotne oprzeć ją o wykładnię historyczną przepisów, a także o dorobek innych nauk, w tym zwłaszcza zarządzania personelem. W tym ostatnim przypadku istnieje możliwość właściwej interpretacji takich pojęć, jak „wartościowanie stanowisk pracy” (dla określenia płacy jednakowej wartości), „ocena pracownika" (dla określenia ,umiejscowienia pracownika” w widełkach płacowych) czy „kultura organizacyjna” (dla uzasadnienia szerokości zastosowanych widełek lub kryteriów decydujących o tym, za co wynagradza się w konkretnej organizacji). Dopiero ta wiedza umożliwi, moim zdaniem, właściwą ocenę aktualnie obowiązujących uregulowań zakładowych oraz postanowień indywidualnych umów o pracę z punktu widzenia aksjologii różnicowania wynagradzania uzasadnionego „obiektywnymi powodami”. Może też dać podstawę do wdrażania nowych rozwiązań mających na celu prawidłową realizację funkcji wynagradzania w społecznej gospodarce rynkowej ${ }^{67}$.

\section{BIBLIOGRAFIA}

Armstrong M., Zarzadzanie zasobami ludzkimi, Kraków 2007.

Borkowska S., Strategie wynagrodzeń, Kraków 2001.

Davenport T.H., Zarzadzanie pracownikami wiedzy, Kraków 2007.

Jacukowicz Z., Zmiany wewnętrznej struktury wynagrodzeń, Warszawa 1996.

Kozioł L., Piechnik-Kurdziel A., Kopec J., Zarządzanie zasobami ludzkimi w firmie. Teoria i praktyka, Warszawa 2000.

Lanz K., Zatrudnianie i zarządzanie personelem, Warszawa 1994.

Libera T., Komentarz ustawy z 20.07.1990 r. o wliczaniu okresów pracy w indywidualnym gospodarstwie rolnym do pracowniczego stażu pracy, [w:] Prawo pracy. Akty wykonawcze. Komentarz, pod red. W. Muszalskiego, K. Walczaka, Warszawa 2002.

Liszcz T., Prawo pracy, Warszawa 2011.

Piankowski M., Ochrona pracowniczych świadczeń majątkowych, Bydgoszcz - Gdańsk 2002.

Prechuta K., Zarzadzanie wiedza w przedsiębiorstwie, Warszawa 2005.

R.J. Nobile Essential Facts: Employment Edition 2010-2011, Danvers 2010.

Salwa Z., Nowelizacja przepisów o tworzeniu zakładowych systemów wynagradzania, „Praca i Zabezpieczenie Społeczne" 1990, nr 10.

Szubert W., Uktady zbiorowe pracy, Warszawa 1960.

Świątkowski A.M., Międzynarodowe prawo pracy, t. 1: Międzynarodowe publiczne prawo pracystandardy międzynarodowe, Vol. 2, Warszawa 2008.

${ }^{67}$ Szerzej na ten temat piszę w opracowaniu: Funkcje wynagrodzeń w spolecznej gospodarce rynkowej-teoria i praktyka, [w:] Studia z zakresu prawa pracy i polityki społecznej, pod red. A.M. Świątkowskiego, Kraków 2012, s. 109 i n. 
Święcicki M., Prawo pracy, Warszawa 1963.

Walczak K., [w:] Prawo urzędnicze. Komentarz, pod red. K.W. Barana, Warszawa 2014.

Walczak K., Aksjologiczne podstawy wynagradzania zatrudnionych w gospodarce postindustrialnej - wybrane zagadnienia, [w:] Aksjologiczne podstawy prawa pracy i ubezpieczeń spolecznych, pod red. M. Skąpskiego, K. Ślebzaka, Poznań 2014.

Walczak K., Autonomiczne źródła prawa dotyczacego wynagradzania, „Monitor Prawa Pracy” 2014, $\mathrm{nr} 1$.

Walczak K., Dopuszczalność zwolnienia się z postanowień ponadzakładowego uktadu zbiorowego pracy przez pracodawców indywidualnych, [w:] Aktualne zagadnienia prawa pracy i polityki socjalnej. Zbiór studiów, pod red. B.M. Ćwiertniaka, Sosnowiec 2012.

Walczak K., Funkcje wynagrodzeń w społecznej gospodarce rynkowej-teoria i praktyka, [w:] Studia z zakresu prawa pracy i polityki społecznej, pod red. A.M. Świątkowskiego, Kraków 2012.

Walczak K., Pojęcie pracodawcy w polskim prawie pracy $i$ wynikajace z niego problemy praktyczne, [w:] Aktualne zagadnienia prawa pracy i polityki socjalnej. Zbiór studiów, pod red. B.M. Ćwiertniaka, Sosnowiec 2012.

Walczak K., Postanowienia autonomicznych źródet prawa pracy obowiazujacych u pracodawców - przedsiębiorców zwiększajace wymiar emerytury, [w:] Materiaty pokonferencyjne IV Seminarium Szubertowskie. Współczesne problemy prawa emerytalnego, pod red. M. Włodarczyka (w druku).

Walczak K., Problematyka wynagradzania pracowników w uktadach zbiorowych pracy. Teoria i praktyka początku drugiej dekady XXI wieku w świetle poglądów Wacława Szuberta, [w:] Uktady zbiorowe pracy. W stulecie urodzin Profesora Wacława Szuberta, pod red. Z. Górala, Warszawa 2013.

Walczak K., Regionalizacja wynagrodzeń a zasada niedyskryminacji pracowników, „Gdańskie Studia Prawnicze" 2013, t. XXX.

Walczak K., Staż pracy jako podstawa różnicowania wynagrodzenia pracowników. Teoria i prakty$k a$, ,Monitor Prawa Pracy” 2014, nr 3.

Walczak K., Wartościowanie stanowisk pracy ustawowym obowiąkiem pracodawcy?, „Monitor Prawa Pracy" 2004, nr 9.

Walczak K., Zasada formalizmu wynagradzania w ujęciu historycznym, [w:] Materiały pokonferencyjne V Seminarium Szubertowskiego. 40 lat Kodeksu pracy, pod red. Z. Górala (w druku).

Walczak K., Zasady wynagradzania pracowników wynikajace z prawa pracy i ich porównanie z praktyka firm oraz teoria zarzadzania personelem, [w:] Aktualne problemy zarzadzania teoria i praktyka. Monografia naukowa z okazji 40-lecia Wydziału Zarządzania Uniwersytetu Warszawskiego, Warszawa 2012.

\section{SUMMARY}

The subject of this article is related to interpretation of the principle of non-discrimination in remuneration. In author's opinion is essential to carry processes of job and employee evaluation in order to justify legitimacy of employers activities. Correct introduction of these processes will enable suitable estimation of document in the field of remuneration such as a collective labour agreements, pay regulations and employment contracts.

Keywords: Labour Code; non-discrimination; remuneration; collective labour agreement; pay regulation; employment contract; job evaluation; high potentials 